International Review of Social History 43 (1998), pp. 235-263

(C) 1998 Internationaal Instituut voor Sociale Geschiedenis

\title{
Migration and Opportunity: An Antipodean Perspective
}

\author{
Robin Haines, Margrette Kleinig, Deborah Oxley and \\ ERIC RICHARDS ${ }^{\mathrm{D}}$
}

Summary: Australian data can reflect on British questions, about the quality of immigrant labour, and the opportunities gained by migrating, in the nineteenth and early twentieth centuries. Three case studies are presented. The first uses quantitative methods and convict transportation records to argue that Ireland suffered a "brain drain" when Britain industrialized, siphoning off the cream of its workers to England and some, eventually, to Australia. Drawing on an entirely different type of data, the second study reaches strikingly similar positive conclusions about the qualities of Australia's early assisted immigrants: three splendidly visible immigrants stand for the tens of thousands of people who sailed out of urban and rural Britain to the distant colonies. A no less optimistic view of Australia's immigrants half a century later is demonstrated in the third case study on female domestic servants. Often referred to as the submerged stratum of the workforce, the most oppressed and the least skilled, the label "domestic servant" obscured a wide range of internal distinctions of rank and experience, and too often simply homogenized them into a sump of "surplus women". This study helps to rescue the immigrant women from this fate and invests them with individuality and volition, offering the vision of the intercontinentally peripatetic domestic, piloting her way about the globe, taking advantage of colonial labour shortages to maximize her mobility and her family strategies. Best of all, these migrants emerge as individuals out of the mass, faces with names, people with agenda.

\section{NEW DIRECTIONS IN THE HISTORY OF AUSTRALIAN I M M I GRATION}

Australia was part of the outer periphery of nineteenth-century migration systems. Compared with the American theatres it was a late starter in the intercontinental transfer of labour as the Australian colonies did not recruit substantial numbers of free immigrants until the i840s. Nevertheless, in the course of the nineteenth century, Australia received about I.6 million migrants and drew them almost entirely from the British Isles. This was the

I. Deborah Oxley takes responsibility for the section on convicts; Robin Haines is responsible for the section on the mid-nineteenth century; Margrette Kleinig contributed the section on the early twentieth century; and Eric Richards provided the frame and drew the threads together. All four authors wish to thank the Labour History Conference, Adelaide, September 1995, for offering us a forum in which to air our views. 
longest distance migration in human history, a remote expression of the great European outreach in the age of mass migration. Much of the Australian variant is unusually well documented and therefore provides a parallel testing ground for many of our prevailing ideas about the evolution of international migration.

For the Australian immigration story no equivalent of Oscar Handlin or Bernard Bailyn has yet emerged to write a saga-like narrative of the process. Over the past decade, however, new Australian research has begun to tackle several key elements in the story in novel and systematic ways, using new evidence and new techniques of analysis. We are witnessing the reshaping of Australian immigration history in the colonial period. Here, as elsewhere, much of the theoretical and empirical work on non-coercive international migration relates to the operations of labour markets and the response of potential migrants to income differentials and social change in donor and receiving countries. In terms of verifying the central propositions in this field, analysis is almost always of two sorts. The first employs aggregate statistical data to test the scale and velocity of the transit of migrants and their impact on wage movements. ${ }^{2}$ The second approach deals with the individual and collective identities of the actual migrants and attempts to deduce mechanisms and mentalities from the composition and character of the migrating populations. ${ }^{3}$ In Australia there has been work of both sorts, though recent tendencies suggest that quasi-ethnographic research has taken a short lead. ${ }^{4}$

The Australian story was always heavily segmented both in its clear-cut chronology and in its segregated categories of immigrants. It commenced with coerced penal labour, and progressed to free immigration which was itself bifurcated between streams of the assisted and the unassisted. This paper covers three of the largest components in the formation of the Australian labour force in the nineteenth century: convict immigrants who, with their offspring, constituted virtually the entire colonial workforce until I840; the assisted immigrants of the mid-century who comprised most of the free immigrants before the gold rushes (1852-1855); and one of the two largest occupational categories of immigrants, female domestic servants, who came out as part of the great surge of British emigration in the late nineteenth and early twentieth centuries.

No account of Australian labour history can fail to give prominence to these three components of the incoming population. More original, however, is the manner in which these Australian immigrant studies reflect back

2. See, as a perfect example, the recent collection edited by Timothy J. Hatton and Jeffrey G. Williamson, Migration and the International Labor Market, I850-1939 (London, 1994).

3. The most substantial corpus of this type of work is by Charlotte Erickson, especially Invisible Immigrants (London, 1972) and her essays Leaving England (Ithaca, 1994).

4. See especially David Fitzpatrick, Oceans of Consolation: Personal Accounts of Irish Migration to Australia (Melbourne, Cork and Ithaca, 1995). 
on conditions in contemporary Britain and Ireland. Each uses Australian data, statistical and literary, to illuminate aspects of Britain, especially the character of the British labour market. This is most observable in the windows it opens on the mobility of labour in Britain, on employer attitudes, prolertarian psychology and the incipient integration of British and colonial labour markets. There is an unusual reversal here: Australian data for British history. In historiographical terms it is, for once, a case of the empire striking back. The Australian colonies received large numbers of Irish migrants, many of whom had given prior service in the British labour market. This sequence was already found in the earlier careers of Irish female convict migrants to New South Wales before I840, as analysed in the following section.

\section{"CROWDS OF MISERABLE IRISH": PRE-FAMINE IRISH EMIGRATION TO GREAT BRITAIN}

Even before the Great Famine of the I840s, migration was a key feature of the Irish economy. North America was a popular destination for Irish migrants, but travelling such distances was costly with well-paying jobs a prerequisite to saving the necessary fare. ${ }^{5}$ Australasia was further and more expensive: even a "free passage" required money for travel within Ireland, provisions for the voyage, and relocation expenses. ${ }^{6}$ England, being closer, was more easily reached at cheaper cost. A deck passage could be purchased for as little as threepence. ${ }^{7}$ Crossing the Irish Sea offered hope of employment in the burgeoning industrial towns of England and Scotland. British counties were even feasible destinations for Irish seasonal workers. ${ }^{8}$ Nearly 200,000 Irish-born women were living in England, Scotland and Wales at the time of the I84I British census. ${ }^{9}$

In I839, the English social critic Thomas Carlyle reflected on these Irish migrations, noting dismally how "crowds of miserable Irish darken all our towns" ${ }^{\text {Io }}$ His view was coloured by a belief that these workers were uneducated, poorly skilled, unaccustomed to hard work and consequently destined

5. For example, in I83I 62 per cent of Irish emigrants travelled to the USA, while 4.5 per cent went to Australasia: Charlotte Erickson, "Emigration from the British Isles to the U.S.A. in I83I", Population Studies, 35 (198I), p. I8I.

6. Robin Haines, “'The Idle and the Drunken Won't Do There': Poverty, the New Poor Law and Nineteenth Century Government-Assisted Emigration to Australia from the United Kingdom”, Australian Historical Studies, 28, I08 (April 1997).

7. Stephen Nicholas and Peter Shergold, "Human Capital and the Pre-famine Irish Emigration to England", Explorations in Economic History, 24 (1987), p. I59.

8. John Mannion, "Migration and Upward Mobility: The Meagher Family in Ireland and Newfoundland, 1780-1830", Irish Economic and Social History, XV (1988), p. 69.

9. "Great Britain census 184I. Report from the Commissioners", British Parliamentary Papers (hereafter PP) I843 (496) XXII, pp. I4-I6 (IUP Population 3).

Io. Thomas Carlyle, Chartism (London, I839). 
to a life of misery and poverty. This opinion was shared by Friedrich Engels, among many. Scathingly Engels wrote,

the dissolute, volatile, and drunken Irish are unfitted for tasks which demand either a regular apprenticeship or that degree of skill which can only be secured by a long period of unremitting application to one's job [. . . The Irishman, however, is just as capable as the Englishman of undertaking simple tasks involving brute strength rather than skill and precision. ${ }^{\mathrm{II}}$

In similar vein, the 1836 Report on the state of the Irish poor in Great Britain had concluded that together these individuals provided

an example of a less civilized population spreading themselves, as a kind of substratum, beneath a more civilized community, and, without excelling in any breach of industry, obtaining possession of all the lowest departments of manual labour. ${ }^{\mathrm{I}}$

Depicted as unskilled labourers flooding into the country in great numbers, accepting low wages and poor conditions, cramping available housing and living in squalor in Irish/Catholic urban ghettos, and competing with British workers, the Irish were blamed for eroding living standards and widening the gap between the haves and have-nots apparent in early industrial society. But there were advantages for employers: cheap manual labour that depressed other wages reduced production costs, thus enlarging markets and profits. Irish immigrants were the shock troops of British industrialization.

These contemporary estimations became historical orthodoxy. Much of the literature has followed one theme: pre- or post-famine, poverty pushed overseas Ireland's least capable and inferior workers, to the detriment of the receiving country. The Irish influx had a "disastrous social effect", ${ }^{13}$ with unskilled Irish workers unable to find a comfortable niche in the great metropolis of London and elsewhere. ${ }^{14}$ Even in the most revisionist of articles - where Jeffrey Williamson has argued that living standards, rising inequality and the marginal cost of labour were all unaffected: "Irish immigrations were simply too small to matter much" because the British economy had become a great sponge capable of absorbing all the labour poured into it - at its core remains the "conventional wisdom" that Irish immigrants only competed against those manual workers at the bottom of the heap. ${ }^{\text {Is }}$ Studying the "outcast Irish" in the British Victorian city, Roger Swift concluded that Britain received the poorest of all Irish immigrants, those unable to pay fares to go to America or afford the costs involved in reaching Australia, with the consequence that Irish immigrants into Britain were "largely

II. Friedrich Engels, The Condition of the Working Class in England (Oxford, 1971), p. I07.

I2. Quoted in Roger Swift, "The Outcast Irish in the British Victorian City: Problems and Perspectives”, Irish Historical Studies, 25, 99 (May 1987), p. 266.

13. Arthur Redford, Labour Migration in England, I800-I850 (Manchester, 1926).

I4. Lynn Hollen Lees, Exiles of Erin: Irish Migrants in Victorian London (Manchester, 1979).

I5. Jeffrey Williamson, "The Impact of the Irish on British Labour Markets During the Industrial Revolution", Journal of Economic History, 46, 3 (September 1986), p. 720. 
illiterate and unskilled". ${ }^{16}$ While by this calculation Irish emigrants venturing further afield should have possessed better resources and greater human capital, other historians have reached similarly pessimistic conclusions about the Irish in America and Australia. ${ }^{17}$ Provocatively, using age-heaping as a measure of numeracy, Joel Mokyr and Cormac Ó Gráda deemed that Irish emigration to North America aided Ireland by removing the "less educated and less able". ${ }^{18}$

Iconoclastically, Stephen Nicholas and Peter Shergold, using mainly male convict data, cast doubt on all these arguments with the claim that "the Irish emigrants did not come to England unskilled - they were made unskilled". ${ }^{19}$ Systemic discrimination accounted for the concentration of Irish male workers in the secondary labour market with its low wages, lack of career path and insecure employment. Other historians have also cast doubt on the conventional wisdom through analysing Irish behaviour within Britain. Evidence has emerged suggesting a more varied occupational structure for Irish immigrants depending upon local economic conditions, less reliance on poor relief and a more diverse ethnic social system. ${ }^{20}$ New research thus demands that we reappraise that old evaluation of the Irish origins as essentially illiterate and unskilled. And this is not idle speculation. If this old depiction is incorrect, we may in fact be identifying an Irish "brain drain" that contributed to Ireland's failure to revolutionize agriculture and industry in the first half of the nineteenth century, pushing it along the tragic path that, in one decade alone, left one million dead and another million fleeing from starvation.

Individual-level data on pre-famine emigrants to Britain are not readily found, with an important exception: Australia's convict records. ${ }^{21}$ Convict indents richly detail the characteristics and backgrounds of each individual transported to the Australian colonies in punishment for their (mainly) minor criminal proclivities. From I826, systematic reporting was made of each person's name, age, education, religion, marital status, number of children, native place, trade or calling (up to four), offence, where and when tried, sentence, former convictions, height in feet and inches, complexion, colour of hair and eyes, plus remarks (such as "scar on left eye"). These data

16. Swift, "Outcast Irish", pp. 265-266.

17. For the Australian literature see Robert Bowden Madgwick, Immigration into Eastern Australia (Sydney, 1937); Raymond Maxwell Crawford, Australia (London, 1952); Geoffrey Blainey, A Shorter History of Australia (Melbourne, 1994); Paula Hamilton, "Tipperarifying the Moral Atmosphere': Irish Catholic Immigration and the State 1840-1860", in Sydney Labour History Group, What Rough Beast? The State and Social Order in Australian History (Sydney, 1982).

I8. Joel Mokyr and Cormac Ó Gráda, "Emigration and Poverty in Prefamine Ireland", Explorations in Economic History, I9 (1982), pp. 377-378. Also see Cormac Ó Gráda, Ireland Before and After the Famine: Explorations in Economic History I800-1925 (Manchester, 1988), p. 35.

19. Nicholas and Shergold, "Human Capital", p. 173.

20. This research is reported in Swift, "Outcast Irish", pp. 267-268.

2I. Also see shipping lists for assisted immigrants. 
are robust and the convicts representative of workers more generally. ${ }^{22}$ Because we know where a convict was born, and where tried, we have a measure of migration prior to exile. (This yields a lower-bound estimate as it fails to detect any individual who, having moved, returned home before offending and sentencing.) Between 1826 and 1840 the penal colony of New South Wales received 2,326 English girls and women, 3,333 females despatched directly from Ireland and, significantly, another 535 Irish women transported only after first migrating to live, work and commit a crime in England, Wales or Scotland: these represented the Irish women abroad. Fourteen per cent of all Irish-born female transportees had first emigrated to Britain. In these years, only twenty-seven British convict women - I per cent - were convicted in Ireland. From convict records we can thus draw a picture of who it was that chose to emigrate, and by measuring levels of literacy, numeracy and occupational skills - indicators of "human capital" we can question claims that Ireland lost to emigration only its least skilled and least desirable members.

Typically, historians have measured Irish migrant workers by the standards of the English and Scottish workers against whom they competed, and found the Irish wanting. Such a result was quite predictable. These workers issued forth from very different economies: an industrializing Britain and a largely agricultural and even de-industrializing Ireland. Certainly, it will be seen that the convict data support the contention that the two economies delivered markedly different levels of human capital to their workers. Irish workers may not have matched the skills of British workers but that is hardly the relevant yardstick. More helpful is comparison within the Irish convict women themselves, between those who did emigrate to Britain prior to their penal transportation and those who did not. Convict occupations can be grouped into W.A. Armstrong's social-skill classification (unskilled, semi-skilled and skilled), facilitating comparison between Irish women who were convicted in Ireland with Irish women who were convicted in Britain. ${ }^{23}$ One-quarter in each group were classified "unskilled", but it was the Irish women convicted in Britain who had attained the highest qualifications: nearly half of them (47 per cent) were "skilled", sig-

22. For a discussion of how these records were generated in the nineteenth century, and how they have been tested, see Deborah Oxley, Convict Maids: The Forced Migration of Women to Australia (Cambridge, 1996) and Stephen Nicholas (ed.), Convict Workers: Reinterpreting Australia's Past (Cambridge, 1988). For the class origins of criminals also see Douglas Hay, Peter Linebaugh and Edward P. Thompson, Albion's Fatal Tree: Crime and Society in Eighteenth-Century England (London, 1975); David Jones, Crime, Protest, Community and Police in Nineteenth-Century Britain (London, 1982); David Philips, Crime and Authority in Victorian England: The Black Country I8351860 (London, 1977); George Rudé, Criminal and Victim: Crime and Society in Early NineteenthCentury England (Oxford, 1985).

23. Walter A. Armstrong, "The Use of Information About Occupation", in E.A. Wrigley (ed.), Nineteenth-Century Society: Essays in the Use of Quantitative Methods for the Study of Social Data (Cambridge, 1972). 
nificantly more than the 37 per cent skilled among convicted women who had remained in Ireland. This suggests that it was workers with higher levels of skill who chose to cross the Irish Sea in search of greater rewards for their labour, or that the chances for completing apprenticeships improved upon departure from Ireland.

With a mean age of nearly twenty-nine years, Irish women convicted in Britain were on average two years older than Irish women convicted at home, but Figure I dispels any suggestion that the former were more skilled simply because they were older. The figure plots the percentage of skilled workers in each age for both groups. In each age category Irish women convicted in Britain outperformed Irish women convicted at home. This figure is important for a second reason. It also includes skill levels for English convict women. From this, there is little doubt that women in the English economy had greater opportunity to invest in their human capital than did their Irish sisters: over a longer period, and achieving higher overall levels. As an individual matured she become more highly skilled and, exposed to an ever-changing labour market, more widely equipped. There was a rapid learning phase between childhood and the adolescent years and through into the mid-twenties. The paths followed in Ireland and England diverge at this point, with England offering its women opportunities for higher levels of investment in education at older ages. For Irish women stasis was reached at this point around the early twenties, even diminishing in later years, while in England women continued their training and retraining, not reaching anything like a plateau until into their thirties. Significantly, the skill levels of Irish women convicted in Britain were greater than those of Irish women convicted in Ireland. Irish convict women who had migrated to Britain before being convicted of an offence were less skilled than English convict women, but they were more skilled than Irish convict women who remained in Ireland. (So few women beyond the age of forty makes the graph unstable in this region.)

Literacy tells a similar tale. Figure 2 compares levels of convict literacy for Irish women tried at home, Irish women tried in Britain and English female convicts. Clearly Irish levels do not match those generated in England, but it is also evident that Irish women who had first migrated to Britain outstripped those who remained to be convicted in Ireland. Literacy was an important influence on migration. ${ }^{24}$ Higher levels of literacy reduced barriers to movement through facilitating knowledge of the new destination and its employment potentials. Irish convict women who were tried in the county of their birth were less literate (could neither write nor read) than those who moved between counties within Ireland (45 per cent as against 52 per cent), who were in turn less literate than those venturing further

24. On this topic see David Fitzpatrick, “'A Share of the Honeycomb': Education, Emigration and Irishwomen", Continuity and Change, I, 2 (1986). 


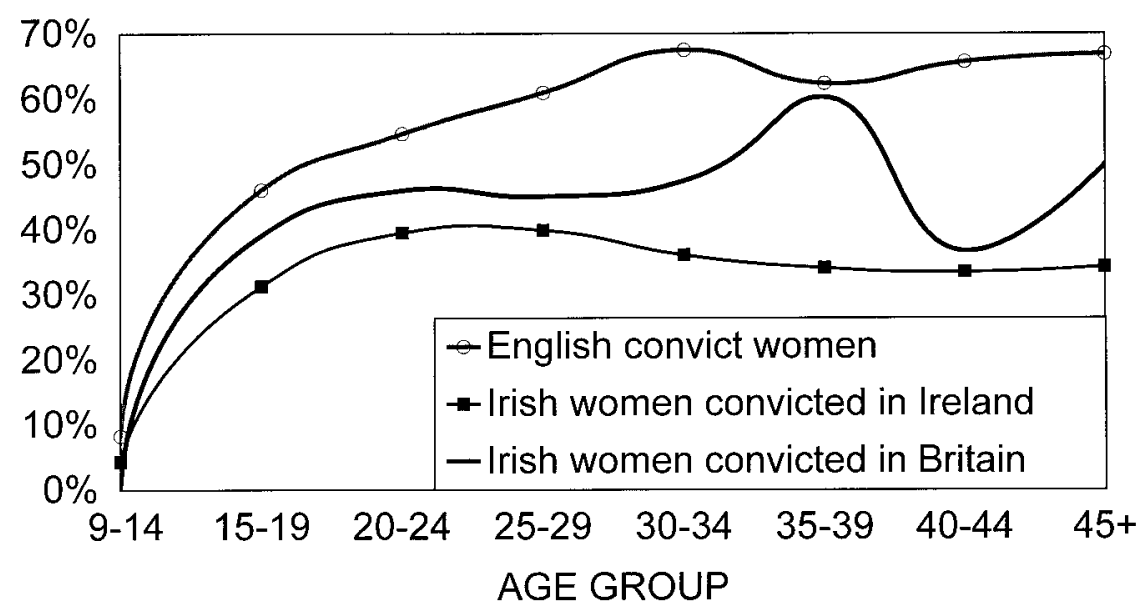

Figure I. Percentage of skilled convict women at each age

Source: Convict indents of transported Irish prisoners 4/7076-7078 \& convict indents of transported prisoners 4/4003-4019, Archives Office of NSW, I826-1840.

afield to Britain (64 per cent). Twice as many migrant convicts could both read and write than could women deported directly from Ireland. Numeracy, measured by "age heaping" and depicted in Figure 3, confirms that Irish women convicted in Britain possessed superior instruction: 25 per cent of Irish women convicted in Ireland gave rounded ages suggesting innumeracy, compared with ig per cent of Ireland's more adventurous women tried abroad. Compared with non-convict Irish women recorded in the $184 \mathrm{I}$ census, emigrants were more skilled ( 47 per cent compared with 22 per cent), less innumerate ( 19 per cent compared with 28 per cent) and less illiterate $\left(36\right.$ per cent compared with 55 per cent). ${ }^{25}$

By Irish standards, these workers convicted overseas in Britain were the pick of the Irish crop: they were the most literate, numerate and highly skilled, each with a range of job experiences. One example of this tendency was the multi-skilled Catherine Grimes, transported to Australia on board the Competitor in 1828. Catherine was a chair carver and sometime washerwoman who could both read and write. She was born in Tralee, County Kerry, and thirty-five years later with one husband dead and buried, Catherine was in London being tried for stealing a bed. Less widely skilled was Catherine Barr, a cook, transported in I839 on the Planter. Born in the city of Waterford, she had been tried in Surrey for stealing a ham. Catherine Barr could read. She was thirty-six, a Protestant, and married with three children.

25. "Report from the Commissioners Appointed to Take the Census of Ireland for the Year I84I", PP I843 (504) XXIV. 


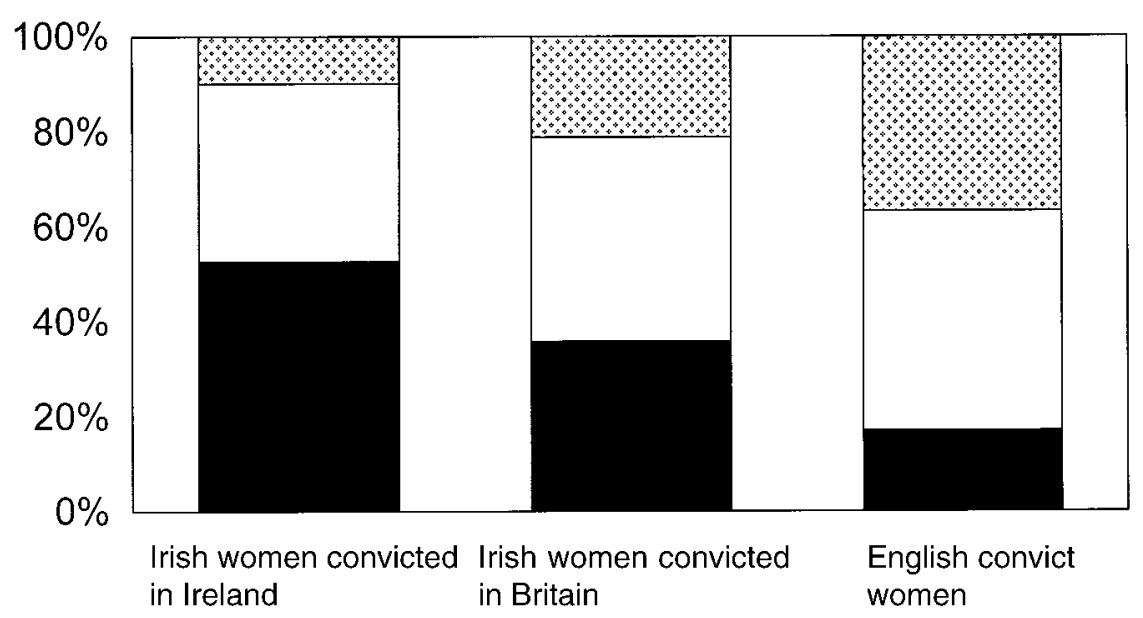

neither $\square$ reads $\quad$ reads \& writes

Figure 2. Percentage literacy rates for women

Source: Convict indents, I826-I840.

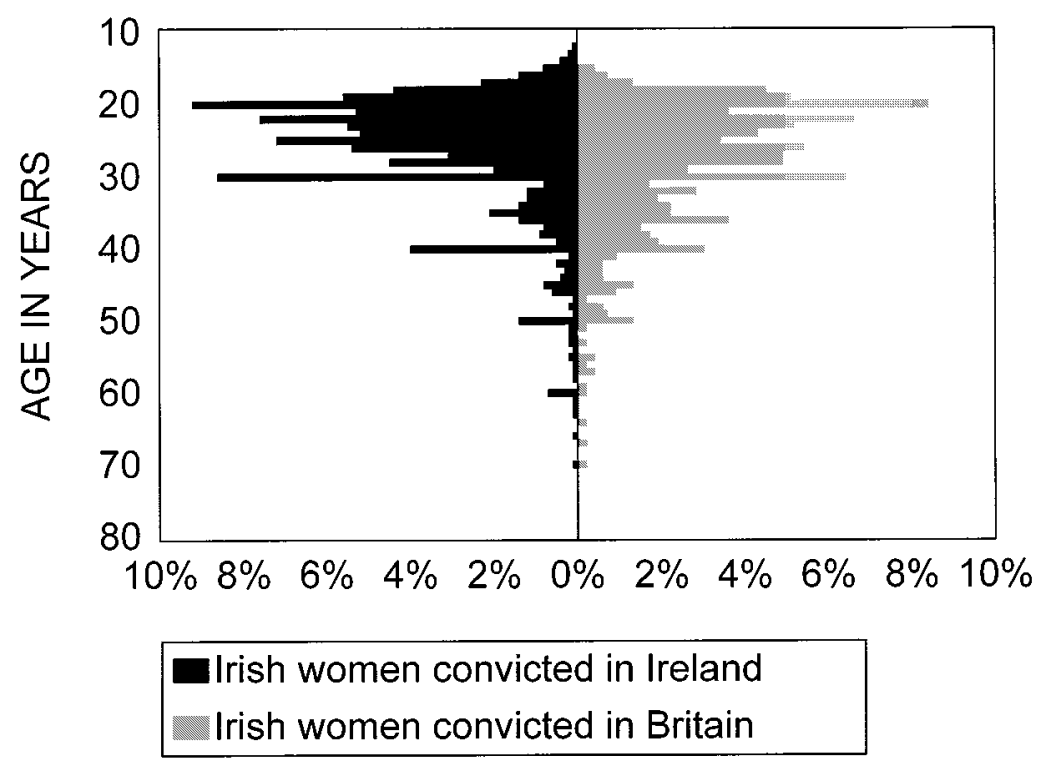

Figure 3. Age heaping among Irish women

Source: Convict indents, $1826-1840$. 
What motivated these particular women to migrate to Britain? Religion? Location? Husbands? Proportionally more Protestants left, perhaps because theirs was a minority religion, or because superior access to education bought them saleable skills that could earn more elsewhere. Push factors were geographically uneven, and Ireland's emigrants came disproportionately from the southern half of Ireland: the regions of Leinster and Munster, both with ready access to ports. Fifty-three per cent of Ireland's women lived in the south, and yet 72 per cent of Irish women convicted in Britain originated there. Connaught, on the other hand, was poor but difficult to leave, while Ulster's relative buoyancy presented charms that retained its workers in a manner that poorer Munster and Leinster could not. Most migrated later to be tried in England - 486 of them - while another 45 were convicted in Scotland, three in Wales and one on the Isle of Man. In Britain, over one-fifth plied their trades in the familiar environment of low-wage agriculture, but the very sizeable proportion of some threequarters aimed for the industrial counties such as Lancashire. ${ }^{26}$

Perhaps the most noticeable feature that divided those tried at home with those tried in Britain was whether a woman was married or not, and this may provide a key to what motivated their movements. Robert Kennedy noted that it is generally easier for single people to migrate than for those already married, that this was especially so for single women compared with wives and mothers, and that after the late I840s Irish out-migration was exceptional for its domination by single travellers. ${ }^{27}$ The a priori assumption, then, would be for a preponderance of single women among the Irish abroad. Not so. As can be seen in Figure 4, in each age band, Irish women convicted abroad were considerably more likely to have experienced marriage. Either the two Catherines had migrated with their husbands, or they may have met their men after moving to England in search of work. Following from their higher marriage rate, more British-tried Irish women were mothers: 65 per cent of Irish-tried women and 62 per cent of English-born female convicts were single when transported, compared with only 47 per cent of Irish women convicted after moving to Britain. This would seem to suggest that skills, marriage and migration all went together. Either migration arose from family decisions, based less on the individual woman's own employment potentials as upon those of her husband and even her elder children, or single women were lured into travel not only by the prospect of work, but of marriage. On the reasons why women emigrated, we can only make inferences from the convict data.

26. Michael Anderson, "Urban Migration in Nineteenth Century Lancashire: Some Insights into Two Competing Hypotheses", in Michael Drake (ed.), Historical Demography: Problems and Projects (Milton Keynes, 1974), pp. I3I-I44.

27. Robert Kennedy, The Irish: Emigration, Marriage, and Fertility (Berkeley, 1973), pp. 70, 85. 


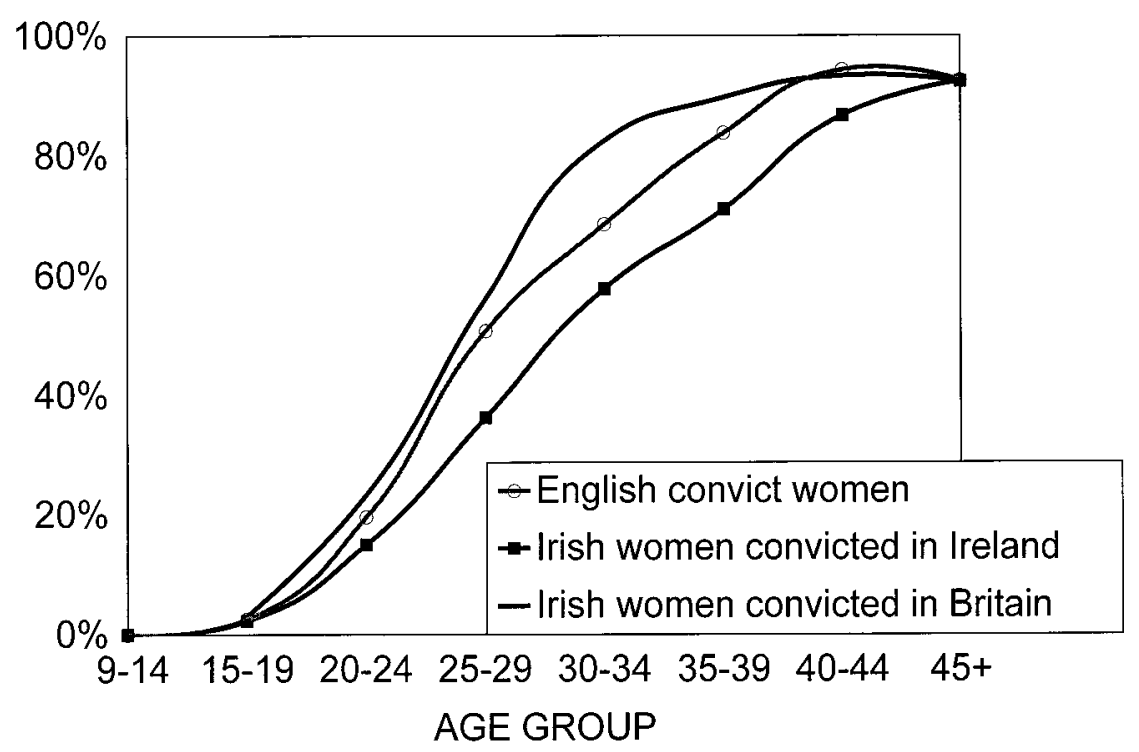

Figure 4. Percentage of married women at each age Source: Convict indents, I826-I840.

In I8I6 David Ricardo bemoaned, "the young, the strong, the enterprising and industrious families leave us, whilst the old, the idle and the indolent portions stay with us". ${ }^{28}$ Mokyr and Ó Gráda conceded that their own occupational analysis of Irish emigrants to America "could be seen as consistent with a 'human capital drain'" ${ }^{29}$ Those who chose to emigrate were not the illiterate, innumerate and unskilled; they were not inept workers forced out by economic failure, a loss that Ireland could only celebrate. They were the cream of Irish workers: those young people who could read about the promise of other places, more highly trained workers who travelled in search of greater pay and improved conditions, who sought to improve their lot in another land..$^{30}$ Every county in Ireland contributed to this outward flow, some more than others; half came from Cork and Dublin, with lesser numbers from Limerick and Antrim. Derry, Galway, Kerry, Roscommon, Tipperary and the rest of the Irish counties all offered up the human fruit of their land to Britain. Even before the famine, Ireland was experiencing a significant loss of talented workers that could only have hindered economic expansion. Cheap migration allowed labour to seek out capital. Had this ex-rural workforce remained in Ireland, available for new

28. David Ricardo, quoted in Nicholas and Shergold, "Human Capital", pp. 158-159.

29. Mokyr and Ó Gráda, "Emigration and Poverty", pp. 377-378.

30. For a discussion see ibid. and Nicholas and Shergold, "Human Capital", p. I59. 


\section{Robin Haines, Margrette Kleinig, Deborah Oxley and Eric Richards}

exploits, capital may have been attracted to it..$^{3 \mathrm{I}}$ This was a vicious circle: domestic economic failure pushed migrants out while better opportunities elsewhere pulled them away; the loss of skilled workers in turn inhibited productivity, investment, growth and development, and the trap was set. This had a social side: as men left, the marriage market worsened. For various reasons, Irish women left too, at a rate comparable with men. While Ireland would mourn this loss, such workers could assist in building the economies to which they emigrated. Eventually, for these 535 women, their labours were transferred to Australia.

By 1840 convict immigration was eliminated from most Australian colonies and was replaced by schemes of assisted immigration from the British Isles. Privately-financed immigration greatly accelerated during the gold rushes of the I850s. The character of the assisted stream is considered in the next section.

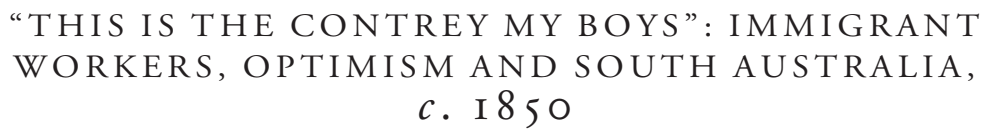

In the mid-I850s, a steerage passage from the United Kingdom to Australia cost an average of $£_{17}$, about equal to the annual wage of a rural male labourer in the south of England and roughly twice that of a female domestic servant. ${ }^{32}$ Consequently, about half of the $\mathrm{I} .5$ million immigrants from the United Kingdom in the nineteenth century travelled with a government-assisted passage on a ship financed by each of the Australian colonial governments. ${ }^{33}$ Although the passage to Australia for approved candidates in the most favoured low-paid occupations was essentially free, there were expenses: a passage deposit was required to cover bedding and mess

3I. Eric L. Almquist, "Mayo and Beyond: Land, Domestic Industry and Rural Transformation in the Irish West", Irish Economic and Social History, 5 (1978), p. 517; Roy F. Foster, Modern Ireland 1600-1972 (London, 1988), pp. 322, 371-372.

32. Steerage fares fluctuated between $£_{I I}$ and $£_{2} O$ during the nineteenth century, rising dramatically during times of crisis like the Crimean War. See John McDonald and Ralph Shlomowitz, "Passenger Fares on Sailing Vessels to Australia in the Nineteenth Century", Explorations in Economic History, 28 (199I), pp. 192-207.

33. Robin Haines and Ralph Shlomowitz, "Immigration from the United Kingdom to Colonial Australia: A Statistical Analysis", Journal of Australian Studies, 34 (1992), pp. 43-52; idem, "Nineteenth Century Government-Assisted and Total Immigration from the United Kingdom to Australia: Quinquennial Estimates by Colony", Journal of the Australian Population Association, 8, I (I99I), pp. 50-6I. Each colonial government financed assisted emigration mainly from the sale of crown land, and each formulated its own selection regulations and conditions. Recruitment of emigrants fluctuated in tune with fluctuating colonial funds and economic conditions but, in some years, the colonies (including New Zealand and South Africa) competed for assisted emigrants. See Robin Haines and Ralph Shlomowitz, "Emigration from Europe to Colonial Destinations: Some Nineteenth Century Australian and South African Perspectives", Itinerario, 20, I (1996), pp. 133I5I. 
utensils; each man, woman and child was expected to provide a set of warm and light clothing suitable for the extremes of heat and cold to be experienced on the voyage; and there were travelling expenses to the port of embarkation. Total costs of a free passage for the most favoured adults (young married agricultural labourers, shepherds and herdsmen and their wives, single female domestic or farm servants, all from among the lowest paid sectors of the economy) was about $\mathfrak{E}_{5}$, or equivalent to an unassisted passage across the Atlantic. ${ }^{34}$ For a large working-class family in these callings, the expense was prohibitive. Australia's immigrants thus needed to be extraordinarily enterprising to find the necessary funds. ${ }^{35}$ Yet this picture of resourceful emigrant workers is at odds with a view of Australia's assisted immigrants which projects an image of nineteenth-century poorer arrivals as urban semi-criminals, lacking in initiative, who were plucked from the workhouses and institutions of the British Isles in an attempt to rid the United Kingdom of its paupers, while simultaneously populating the labour-hungry Antipodes. ${ }^{36}$ If we listen to the voices of three immigrants from England, Ireland and Scotland, we may conclude that Australia's proletariat arrivals deserve a far more positive press.

In September I85I, Jacob Baker, a forty-one-year-old agricultural labourer from a village in Wiltshire in the west of England, arrived in South Australia after a three-month passage on board a sailing ship chartered to carry government-assisted emigrants. ${ }^{37}$ Also on board the Navarino were his fortythree-year-old wife, Charlotte, and their family of nine children, aged one to twenty-three years. Five months after arrival at Port Adelaide, Jacob wrote home to his family and friends in Wiltshire informing them that he had immediately found work on a farm at Lyndoch, north of Adelaide. Four of his older children had been employed as farm labourers, gardeners and domestic servants. "This is the contrey my boys", he wrote, where, at "twelve shillins per week and raishens", wages for day labourers were, effectively, more than double those at home. Not only were rations provided on top

34. For details, see Robin Haines, Emigration and the Labouring Poor: Recruitment in Britain and Ireland, I83I-I860 (London, forthcoming).

35. See Robin Haines, “'Shovelling Out Paupers'? Parish-Assisted Emigration from England to Australia, I834-1847", in Eric Richards (ed.), Poor Australian Immigrants in the Nineteenth Century: Visible Immigrants Two (Canberra, 199I); idem, "Indigent Misfits or Shrewd Operators? Government-Assisted Emigrants from the United Kingdom to Australia, I83I-1860", Population Studies, 48 (1994), pp. 223-247; idem, "Workhouse to Gangplank: The Mobilization of Irish Pauper Women and Girls Bound for Australia in the Mid 19th Century", Irish-Australian Studies (forthcoming).

36. For example, Madgwick, Immigration into Eastern Australia, pp. 188-206, 215, 248 passim; Crawford, Australia; Noel G. Butlin, Forming a Colonial Economy: Australia I810-I850 (Melbourne, 1994), pp. 9, I8-19, 26, 27; Blainey, A Shorter History of Australia, p. 52 passim. For an evaluation of current literature on this theme see Haines, “'The Idle and the Drunken Won't Do There'”. 37. Wiltshire Emigration Society Record Book, Savernake 9, Wiltshire Record Office (also reproduced on AJCP Microfilm M935). 
of wages (" 40 pounds of flour, 40 ditto of meat, beef or mutton, and I pound of tea and 4 pounds of sugger") but, in his case, house rent and firewood were free. Moreover, unlike at home, he and his sons could hunt game without fear of reprisal, and

we have got a goint of fresh meat on our table every day [...] we do not take out a beet of bread and chees into the feeld with us, but all come home to a good hot diner everey day [. . .] we do not put in tea in the pot with a tea spouan, but with the hand. ${ }^{38}$

His employer had provided labour and material to build a house and, pleased with their mowing, had given a bonus of a cow and a calf to Jacob and his eldest son, Timothy, aged twenty-three, while an ox each was promised following the harvest for Timothy and Fred, aged eighteen. It was obviously a great relief for Jacob to write, after all the distress the family faced in Wiltshire, that "all my children can make thiear own forting [fortune] if I should di tomorro".

There is no doubt, from the tone of his letter, that the nonconformist lay preacher felt fortune smiling, "so I pray, brethren, pray for me, that the word may still run and be gloryfied”. His two older daughters Mary, twenty, and Anne, sixteen, were already being pursued by local farmers, and he thought there were prospects for his eighteen-year-old son since "their is another farmer and his wif who have got a farm of their own and ondley one daughter, and this daughter and her mother is very much strock over our Fred, and all they have got is for the daughter", thus Fred only had to play his cards right to win a wife and a farm. These were prospects well beyond the ken of a day labourer living in Wiltshire.

This phonetically-literate farm labourer's testimony is a graphic illustration of the vast difference between his experience in the infant colony and his home in south-west England. There, he had earned about seven shillings per week when work was available and, in I850, winter unemployment left his family even more hungry and in misery than ever. Wiltshire was a county where farmers (among the most prosperous in England) already paid amongst the lowest wages in the country, and where agitation against the repeal of the corn laws by protectionist farmers (who were fearful of the flooding of continental and American grain on to the local market) set them against large landholders, like Lord Bruce of the Savernake Estates and his kin on adjoining estates, who voted for repeal in the House of Lords in $1846{ }^{39}$ Consequently, it was the landless, voteless labourers like Jacob

38. Jacob Baker's letter, dated Is February 1852, was printed in full in the Wiltshire and Devizes Gazette, 22 July 1852, and in The Scotsman, I5 September 1852. See also Mark Baker, "Aspects of the Life of the Wiltshire Agricultural Labourer, c. 1850”, Wiltshire Archaeological Magazine, 74/75 (I98I).

39. On wages, see Keith D.M. Snell, Annals of the Labouring Poor: Social Change and Agrarian England I660-1900 (Cambridge, 1987), pp. I29-130. On the complex debates over the effects on farmers of the repeal of corn laws, see William Van Vugt, "Running from Ruin? The Emigration 
Baker who felt the brunt of the schism between farmers and prominent landlords in a rich farming region where an over-abundance of farm workers militated against their bid to prevent the further reduction of wages.

In February 1850 when farmers in the district announced their intention to reduce wages from seven to six shillings per week for adult males, farm workers demonstrated by letting loose horses, sheep and cattle and persuading field labourers to down tools, and to threaten riots and disturbances. ${ }^{40}$ An articulate, self-educated and conservative nonconformist, Jacob Baker was moved to address a meeting of disgruntled protectionist farmers in his district in the same month. Refused the opportunity to speak, he handed his speech to the editor of the local paper who tidied up the syntax and spelling, and printed it in full the following week.

The speech is an unusual public expression of a labourer's passionate response to free trade at a time, and in a region, where the end of protection, by repealing the protectionist corn laws in 1846 , was thought to have heralded the collapse of farming: an impending disaster, or so they believed, for both farmers and their dependent farm workers. As it happened, the repeal of the corn laws had little impact on English farming for another thirty years by which time improvements in agricultural productivity in North America, Australia, and elsewhere, along with advances in export and transport technology, had gathered enough momentum to affect the United Kingdom's agricultural sector. ${ }^{41}$

In I850, however, barely-restrained panic was widespread in farming districts. Demonstrating a sophisticated comprehension of the major issues relating to free trade, the speech reads as an assurance to farmers that if they merely paid their cold and hungry farm labourers fair wages, provided work for the whole year, improved their estates, benefiting themselves and their workers, the latter would be prepared to help defend their masters against the agitation of radical free-traders. ${ }^{42}$ Emphasizing his self-interest: "I have not half victuals enough, I am come here to know how I can get some more", he continues:

Now, gentlemen, a word to you landowners, monied men, and stewards. Let me entreat you to spend all the money you possibly can in improving your estates, \&c., particularly in cases where by laying out a shilling you can get two by it, and by giving us work and bettering our condition, secure our hearts and good opi-

of British Farmers to the U.S.A. in the Wake of the Repeal of the Corn Laws", The Economic History Review, 2nd ser., XLI, 3 (August 1988), pp. 4II-428, who shows that Wiltshire farmers were among the least affected by repeal: see esp. p. 422. See also Eric J. Evans, The Forging of the Modern State: Early Industrial Britain 1783-1870 (London, 1983), pp. 264-271.

40. "Threatened Disturbance Among Labourers at West Lavington", Devizes and Wiltshire Gazette, 2I February I850.

4I. See Van Vugt, "Running from Ruin?", esp. p. 42I.

42. "Swindon Protection Meeting: A Poor Man's Speech", Devizes and Wiltshire Gazette, I4 February 1850 . 
nions; and then when Cobden and his men come amongst us, we shall still uphold your rights. If the labourers can't be employed now, what will your sons do shortly, when the people are as thick again. Now gentlemen, I am a poor labourer out of work, and with no prospect of any constant work until mowing, and shall be glad if you gentlemen can give me and my son a month or two's work. I can have a good character [reference] from my various masters, and you won't repent giving me a job. I am what is called a hedger and ditcher and copse cutter, but I can plough, sow, reap, thrash and mow, with any man. I am also a rough carpenter, and can make ladders, gates, and common buildings; I can kill and cut up pigs, sink wells, and make roads; I can do your garden, and have done a deal of treeplanting and quick mounds; I can mend my childrens' shoes and make my own clothes, and occasionally earn sixpence by drawing teeth. Now, gentlemen, is not this a shame that I should be out of work and in this distress? and I defy any man to bring any charge against me for dishonesty, drunkenness, or idleness.

Sixteen months later, the Baker family left England. Along with 247 other men, women and children from his district, he had grasped the opportunity offered by the Wiltshire Emigration Society to subsidize the family's kit of clothing and their passage deposits amounting to $\mathfrak{E}_{3} 6$, or the equivalent of about two years' wages for an adult labouring Wiltshire male. ${ }^{43}$ Settling down in South Australia, satisfied and thanking "God for the means which brought us out hear", his wish to own land was fulfilled. ${ }^{44}$ Over the years he described himself variously as a carter, a farmer and, finally, in his will written in I885, as a labourer. He owned four acres of land on his death, aged eighty, and he left $£_{25}$ worth of personal property, a "forting" for a Wiltshire day labourer. ${ }^{45}$

As a rural worker with a large family of adolescent and adult children, Jacob Baker belonged to the occupational category most desired by each of the colonial governments. Perhaps more versatile and articulate than his peers he was, however, typical of the multi-skilled labourers of rural England, some of whom found their way to Australia. His own description of his skills confirms arguments that the terms "field labourer" or "agricultural labourer" or "farm worker" obscures the "multiform nature of the labourer's means of livelihood". ${ }^{46}$ In English towns and industrial villages, field labour-

43. See "Wilts Emigration Association Form of Recommendation", Wiltshire Record Office, Savernake 9. See also Mark Baker, "A Migration of Wiltshire Agricultural Labourers to Australia in I851", Journal of the Historical Society of South Australia, I4 (1986), pp. 67-82.

44. Letter, dated I5 February I852, Wiltshire and Devizes Gazette, 22 July I852.

45. Mark Baker, "Some Early Wiltshire Emigrants to Australia", The Hatcher Review, 2, 17 (1984), p. 333 .

46. Patrick Joyce, "Work", in Francis M.L. Thompson (ed.), The Cambridge Social History of Britain I750-1950, vol. 2 (Cambridge, 1990), pp. I33-I45. See also Francis M.L. Thompson, The Rise of Respectable Society: A Social History of Britain I830-I90o (London, 1988), on the multifunctional nature of labour in the countryside, p. 26 passim; Alun Howkins, "Labour History and the Rural Poor", Rural History, I, I (I990), p. II6, and idem, Reshaping Rural England: A Social History I850-1925 (London, I99I). Walter A. Armstrong emphasizes that although insufficiently recognized by their peers and social surperiors, the agricultural workers required a greater range 
ers like Jacob also worked as woodcutters, quarrymen and miners while simultaneously supplementing their meagre subsistence by foraging, gleaning, allotment-gardening, pig keeping and so on.

Occupational diversity, in an era of irregular and contracting employment, suggests that the labouring classes were capable of a variety of tasks in Australia. There seems no doubt that Australia's expanding economy depended on the "widespread multi-functional activity of the great proportion of the [Australian] workforce" suggesting that the versatility and adaptability of immigrants were attributes needed in the opening up of new regions of European settlement, as well as at home. ${ }^{47}$ Not only were those emigrants who designated themselves "agricultural labourer" on their application form versatile, but government-assisted arrivals to New South Wales between 1848 and I860 disembarked with a strong sense of their ownership of a particular skill, recording 346 different occupations, mostly of a preindustrial rural nature. Moreover, data collected by Immigration Officials as government immigrants stepped ashore in Adelaide, Sydney and Melbourne, suggests that they were remarkably literate, especially if reading, rather than writing, is adopted as a proxy for literacy. ${ }^{48}$

While it is clear for all Australian colonies that among free immigrants Irish women were the most disadvantaged of all readers, the average proportion of readers of both sexes over seven years between I848 and I856 was 84 per cent in Victoria, the proportion for both sexes over the age of seven years arriving between I854 and I860 in South Australia was 79 per cent, and in the same period for the same age-group in New South Wales, the average was $8 \mathrm{I}$ per cent. $^{49}$ Victorian figures are used for illustration in

of skills for which they were not adequately rewarded: see his "The Flight From the Land", in Gordon Edmund Mingay (ed.), The Victorian Countryside, vol. I (London, 198I), p. I24. See also Evans, Forging of the Modern State, p. 169 passim.

47. Noel G. Butlin, "White Human Capital in Australia, I788-1850", Working Papers in Economic History, 32, Australian National University (1985), p. 33.

48. Non-writers with adequate, or even highly developed, reading skills, are invisible in studies which test only for the ability to write. But emigrants were asked if they could "read and write", "read only" or "neither". Thus the Australian immigration data is highly specific. The literacy of immigrants was significantly higher than has been assessed from evaluations of Anglican parish registers which only record the ability to write a signature. See Haines, "Indigent Misfits", pp. 232-235. See also Roger S. Schofield, "Dimensions of Illiteracy 1750-1850", Explorations in Economic History, Io (1973), p. I24, who showed that by about 1840 the ability to sign English marriage registers averaged 67 per cent for men, and $5 \mathrm{I}$ per cent for women, and David Vincent, Literacy and Popular Culture: England 1750-1914 (Cambridge, 1989), p. 24, who found that between 1839 and 1854 the ability to sign the register by brides and grooms belonging to the "unskilled labourer class" was evenly balanced in his sample, at 3I.4 per cent and 31.6 per cent respectively. See also Gillian Sutherland, "Education", in Francis M.L. Thompson (ed.), The Cambridge Social History of Britain, I850-I950, vol. 3 (Cambridge, 1990). See also Thomas Laqueur's debate with Michael Sanderson in "Literacy and Social Mobility in the Industrial Revolution in England", Past and Present, 64 (August 1974), esp. p. I05.

49. Eighty-eight per cent of males and females arriving in New South Wales (NSW) over the age of seven from England could read, 7I per cent from Ireland and 92 per cent from Scotland, 
Table I. Literacy in Victoria, I852-1856: percentage of government emigrants aged seven years or over who could read and write

\begin{tabular}{lcccc}
\hline & \multicolumn{2}{c}{ Total writers } & \multicolumn{2}{c}{ Total readers } \\
& males & females & males & females \\
\hline England \& Wales & 77 & 77 & 93 & 95 \\
Ireland & 59 & 37 & 76 & 70 \\
Scotland & 73 & 66 & 86 & 85 \\
Total & 71 & 59 & 87 & 83 \\
\hline
\end{tabular}

Source: Extracted from the Annual Immigration Reports, published in Votes \& Proceedings, Victoria Parliamentary Papers. The category "total writers" is a subset of "total readers".

Table I since, unlike the data for the other colonies, it is possible to disaggregate the sexes. While religious persuasion cannot be linked to literacy in the aggregate immigration data used in Table $\mathrm{I}$, there was a close correlation between religious adherence and literacy. Cambridgeshire immigrants were far more likely to be able to write if they were Baptist or Independent than if they professed allegiance to the Church of England. While Wesleyans were less likely to be able to write than Baptists and Independents, there were more Wesleyan readers than the other denominations. Defining literacy as the ability to read, Wesleyans at 93 per cent led Independents and Baptists by I per cent, while Anglicans lagged behind at 88 per cent. ${ }^{50}$ It would seem that the United Kingdom's nonconformist Sunday Schools were exerting an impact on Australia, from afar.

Occupation is also closely correlated with literacy for both men and their wives as R.B. Shultz's analysis of government immigrants arriving in New South Wales between 1837 and I850, has shown. ${ }^{\text {SI }}$ As we might expect, skilled tradesmen and their wives showed the highest literacy rates but the highest illiteracy level, of I6 per cent for unskilled male workers, is still remarkably low compared with English measurements using parish registers. Further, the literacy rate for agricultural labourers (readers and writers) at 72 per cent, and unskilled workers at 70 per cent, is nearly double that of the estimated rate from a sample of English marriage registers. ${ }^{52}$ The reading

averaging 8I per cent for the UK. Extracted from the annual reports of the NSW, Victorian and South Australian Immigration Agents published in their respective Parliamentary Papers.

5o. Colin S. Holt, "Family, Kinship, Community and Friendship Ties in Assisted Emigration from Cambridgeshire to Port Phillip District and Victoria 1840-1867" (unpublished M.A. thesis, LaTrobe University, 1987). The ratio of "read and write", "read only" and "neither", as rounded percentages, are Church of England, 67:21:I2; Wesleyan 70:23:7; Independent 79:14:8; Baptist 79:I2:8: p. 227. See also p. I09 and Appendix I4, p. 225.

5I. Robert J. Shultz, "Assisted Immigration into New South Wales and Port Phillip District I8371850" (unpublished Ph.D. thesis, Australian National University, 197I).

52. Ibid., Table XXIV, p. 402. The English marriage register sample was about $3 \mathrm{I}$ per cent for unskilled labourers and their wives: see Vincent, Literacy and Popular Culture, p. 30. Schultz also 
ability of English females and males arriving in New South Wales between I837 and I850 was equal at 9I per cent, remarkably close to the figures for Victoria in Table I where, however, Englishwomen led men as readers. Similarly, the wives of Cambridgeshire agricultural labourers were likely to be more literate than their husbands.

Six months after landing, one typically literate Scottish assisted immigrant who arrived in South Australia in I839 was glad that he "went not to America". Despite the death of his infant daughter within three months of disembarkation, Hugh Watson wrote home to assure his parents that he felt he had fulfilled his grandfather's benediction: "keep thou to the South and thou shalt prosper" ${ }^{53}$ Having "crossed the line with only one sixpence in the world" he engaged himself to a gentleman farmer as a shepherd at one pound per week plus rations, with free house and garden. Hugh was confident of his prospects, "and now I have got plenty and to spare". Not only was the family able to keep a cow and two pigs and fowls tended by another daughter, Isabella, but living on the banks of the River Torrens close to town was a bonus for his wife, Mary, who was able to take in gentlemen's washing, "gaining $\mathfrak{E}_{\mathrm{I}}$ per week which I am sure she would not do in Scotland in a month". Three years later Mary Watson was to die of consumption, by which time Hugh was a cow-keeper, later becoming a farmer, an occupation beyond his scope in Scotland.

Like the deeply religious nonconformist lay preacher Jacob Baker and the Anglican Hugh Watson, who both freely praised God for their deliverance from poverty, an equally religious eighteen-year-old Irish protestant letterwriting orphan, who arrived on the same ship as the Baker family in I85I, similarly sprinkled her letters home with providential praise. Immediately finding work in a draper's shop, where she remained content for several years, like Jacob and Hugh, Isabella Wyly would not have exchanged her fortune in South Australia for life at home in Dublin. Travelling alone as a domestic servant, she arrived "a stranger in a strange Land". Several adult relatives who followed her died soon after arrival but, despite her loss, she wrote home five years later, "I am much better of than I ever should for been atome" ${ }^{54}$ Earning wages well beyond her dreams at home, rising from ten to twelve to fifteen shillings a week, by I857 she was earning the enviable annual wage of $£_{52}$ in a responsible position in the drapery. She revelled in her independence:

found wide regional variations in male literacy rates within England. Still, such comparisons should be viewed with caution given the problems with marriage register sampling and our incomplete understanding of immigrant data collection methods: see Haines, "Indigent Misfits", pp. $232-235$.

53. Letter from Hugh Watson to his parents in Scotland, 9 September I839, Mortlock Library of South Australiana, D6075(L), and accompanying family notes.

54. Letter dated 2 July 1856, from Isabella Wyly to her sister-in-law in Ireland, in Fitzpatrick, "These Golden Shores: Isabella Wyly, I856-77", in his Oceans of Consolation, p. 97. 


\section{Robin Haines, Margrette Kleinig, Deborah Oxley and Eric Richards}

I never felt more happy in my life than I do now that I am independent of everyone. There is no bread sweeter th[an] the bread you work for yourself. I should hav been a long time in poor old Dublin before I should show so well as I have done here. I am very comfortable and happy, and hav great reson to be thankful..$^{55}$

The constant theme of her letters prior to her marriage, aged twenty-seven, to her Irish employer, and the subsequent birth of ten children, was her strong sense of achievement, "I am quite my own Mistress, none to dictate to me" and her Christian belief, "I trust I shall always look to Him who is the Strong for Strength to Gide my steps in to the right path and I am asured I shall never go wrong" ${ }^{56}$ Isabella's faith was justified. Happily married, she and her family eventually moved from the store in Hindley Street to a grocery business in Melbourne where she became the mistress of servants and the mother of nine surviving well-educated children and, she wrote in 1877 in her Irish-accented prose, "South Australia [is] the place I still call home". ${ }^{57}$ The enterprising orphan of middle-class Protestant parents who, like many children of her class, was left destitute and dependent on relatives in childhood, spent "the rest of her long life praising God, her husband, and South Australia". ${ }^{58}$

Common to these three immigrants from England, Scotland and Ireland was their deep sense of faith in God and themselves, their literacy, which no doubt aided them in negotiating the bureaucratic red tape surrounding application and selection for a government-assisted passage, their enterprising spirit and their success as settlers. Given bias inherent even in the survival of letters like these, whether published or unpublished, it is impossible to know how far their testimony typifies the experience of other government emigrants, many of whom experienced severe hardship on landing, to be sure. Thus, it is doubtful whether we can approach anything like a statement of representativeness. But, given robust literacy rates, and their correlation with religious persuasion, it is possible that Jacob, Hugh and Isabella spoke for a high proportion of the evangelical, working-class arrivals even if they were more optimistic, independent and successful than most.

Typicality notwithstanding, it is no doubt worthwhile holding up for inspection the experience of these successful nineteenth-century emigrants, if only to challenge the view that Australia attracted third-rate free-loading immigrants: those who lacked the initiative to finance a passage on a ship crossing the Atlantic and who were merely seduced by the offer of a free passage. Australia's government-assisted immigrants required just as much initiative to finance their deposit and clothing, and faced a more arduous

56. Ibid., letter dated December I857.

57. Ibid., letter dated 2 October 1877, p. I36.

58. Ibid., p. 96. 
voyage with little hope of retracing the expensive 12,000 miles home. The theme of initiative and volition found among the mid-century emigrants was equally manifested in the careers of the young, single, female domestics who migrated in their thousands in later decades. Drawn from the lowest strata of the British labour force, these women give further continuity to the Antipodean immigrant story in the new century.

\section{“A GREAT MANY MORE OPPORTUNITIES": SKILL, SINGLE WOMEN AND EMIGRATION TO SOUTH AUSTRALIA IN THE EARLY TWENTIETH CENTURY 59}

During the nineteenth and early twentieth centuries, the South Australian government granted assisted passages to specially selected emigrants within prescribed occupations. The flow of immigrants was modulated by agricultural seasons and harvests, major public works programmes, private industrial and manufacturing expansion or contraction, the state of the male labour market and general public and political opinion. ${ }^{60}$ The schemes were small and tightly controlled. Single female immigration was firmly wedded to the general migration system and its fluctuations. There was a remarkable consistency in instructions from Adelaide to officials in London concerning the type of female labour required, best expressed in a statement to the Dominions Royal Commission by the South Australian Immigration Officer in 1912: "there is [...] a great shortage of female domestic helpers". ${ }^{61}$ This theme was repeated throughout the colonies and dominions of Australasia, South Africa and Canada, and competition for this form of labour was intense. When decisions were made in South Australia to curtail the assisted immigration programme, the scheme for domestic servants was always the last to cease. Between I9II and 1939, just under 16,000 adult immigrants arrived in South Australia on government-assisted passages from the United Kingdom and Europe. ${ }^{62}$ Just over 1,600 , or Io per cent, were selected single women. ${ }^{63}$

While it is clear that women were selected on the basis of their occupational skills, on arrival their qualifications for the job were sometimes treated with scepticism. Contemporary commentators often expressed dis-

59. Helen Wilson, State Records (of South Australia) (SR, formerly PROSA) GRG 7/8/13I.

6o. Government-assisted immigration during these years covers two periods: I9II-I9I4 and I92I1939. Between 1931 and 1938 state-assisted immigration all but ceased because of the international economic recession.

6I. PP 1914 CD.7I7I, XVII, 36I, Part I, Minutes of Evidence of Mr Edgar John Field taken in Australia in I9I3, App. Ix, p. 83.

62. South Australian Parliamentary Papers (hereafter SAPP), Statistical Registers of South Australia - Population; SAPP, 1929, I94I, vol. I. This figure includes those nominated by friends, relatives and employers, as well as selected arrivals. Very few immigrants arrived from Europe on assisted passages during this period.

63. Ibid., SR GRG Series 7/8, 7/15. 


\section{Robin Haines, Margrette Kleinig, Deborah Oxley and Eric Richards}

satisfaction with the skills of selected single women and these criticisms are scattered throughout the primary sources and reflected in the secondary literature. For example, following the arrival of one emigrant ship in 1922, a report in the Melbourne Argus which alleged abuses of government migration schemes by immigrants included the claim that, "among the domestic servants were a few girls who were 'townies'. Some of them expected to take up shorthand and typewriting". ${ }^{64}$ Roe says of domestics in the interwar period that: "Many Australian voices, and objective evidence too, affirmed that the girls often had little relevant experience [...]" ${ }^{\text {6s }}$ Contemporary complaints about single women, including those from immigration officials, were made for a variety of reasons besides a lack of skill in domestic service. On occasion, the geographical mobility of some workers after arrival, or "exaggerated" expectations concerning the rates of wages payable in Australia, were sources of exasperation. Ironically also, it was seen as problematic that some highly trained domestic servants whose skills were very specialized took time to adapt to Australian conditions and employers' needs for generalists. Criticisms such as these have tended to devalue the skills of emigrants. And yet the Adelaide Register reveals inconsistencies in contemporary opinion. After unfavourably comparing "the imported help" with Australian women, the newspaper noted that, "there are, of course, splendid girls among them". ${ }^{66}$

What, in reality, were the skills of these labour immigrants? First, we can examine the way in which, in the early twentieth century, single women were selected for assisted passages. Second, we can unravel the occupational backgrounds of one group of women who, on the basis of their work skills, grasped an opportunity to move to South Australia in the inter-war period. ${ }^{67}$ Material contained in unpublished government records provides information about the practical selection procedures and the day-to-day management of the scheme. On application, the women were obliged to provide details of their work histories, including length of service in domestic work. The primary requirement was that the women had worked for wages in domestic service. Written references were required from "responsible persons" detailing the applicant's experience in and suitability for domestic work. While references were usually submitted with the application form,

64. Argus, II February 1922, and quoted in David H. Pope, "Contours of Australian Immigration, I9OI-1930”, Australian Economic History Review, XXI, I (March 198I), p. 42. The Argus reported that ten domestic servants were on the ship.

65. Michael Roe, Australia, Britain, and Migration, I9I5-1940: A Study of Desperate Hopes (Cambridge, 1995), p. 229.

66. Register, Adelaide, 8 January 1924, p. 5 .

67. Selected domestic servants were variously called domestic servants, domestics, domestic helpers, domestic workers, home helps and household workers. Roe, Australia, Britain and Migration, ch. 9, includes a discussion on the selection procedures for all categories of emigrants in the inter-war period. 
referees could be, and at times were, applied to directly for testimonials by a government official or an emigration society. Declarations by the women closely correspond with extant evidence from other sources, from references and occasional record annotation or comments from ships' matrons. The majority of these between-the-wars migrants were, in fact, experienced domestic servants. Furthermore, a significant minority of the experienced domestic servants had worked in other occupations and could therefore be broadly termed multi-skilled. This supplementary expertise was available to employers and to the Australian labour market generally.

One accomplished domestic servant was Helen Wilson, who disembarked in Adelaide in July 1923. At thirty-three years of age, she left "a good position [as cook] among a large staff of servants" in Kent. ${ }^{68}$ Pleased with her prospects, Helen wrote to the Immigration Department four months after disembarkation:

Although I gave up a good position and left all my relatives I have not been sorry I came. I find there are a great many more opportunities in this country for both men and women to get on and I have persuaded my sister and her husband to join me, and am expecting them very soon. What strikes me very much here is the lack of poverty one saw all around in England, plainly showing that here there must be plenty of employment. ${ }^{69}$

Helen was satisfied with her move, but how had she secured an assisted passage to this promising land?

Following long convention all assisted emigrants were required to meet eligibility criteria in relation to age, health, occupation, character and marital status. The age criteria for single women was more restrictive than for other adult categories. In the inter-war period, South Australia specified that applicants were to be over nineteen years and under thirty-five years of age. Widows were eligible for selection, provided they were not burdened with young children. These women were therefore at their physical peak - young, healthy, strong and unencumbered with vulnerable dependents. Having passed these tests, however, women faced further exacting regulations. They were each required to undergo individual assessments of their occupational skills and personal character by selecting officials, who interviewed each candidate. ${ }^{70}$

Given the high demand throughout the British empire for domestic servants, perhaps competition between recruiters in the United Kingdom cre-

68. SR, GRG 7/8/I3I.

69. Ibid.

70. Until the First World War, government-assisted emigrants to Australia were recruited and selected by officials of each individual colony. Following the war (and federation in 190I), the government of the Commonwealth of Australia was responsible for the recruitment and selection of assisted emigrants for all states. Commonwealth officials were to select emigrants according to the policy guidelines for each state. 
ated practical limits to the scrutiny to which applicants were subjected. Did theory and practice coincide? Applicants were indeed rejected because they lacked experience in domestic service or because of unsatisfactory references, unacceptable health statements or following personal interview. ${ }^{71}$ In the I920s, little more than one-third of applicants through the Ministry of Labour received assisted passages to Australia as household workers. ${ }^{72}$ Some women also did not proceed beyond the initial enquiry stage.

Although most selecting agents and officials were constrained by the regulations, sometimes the skill requirements for domestic servants were relaxed. This occurred mainly by way of pressure from Australian employers for immigrant workers and from the competition for this form of labour both within and outside the United Kingdom. Just prior to the First World War, South Australian officials accepted "home girls", factory workers and "educated women without domestic experience" if they appeared capable and suitable for private domestic service and expressed a willingness to work within the occupation for at least a year. ${ }^{73}$ Recruiting difficulties in the I920s caused Australian migration officials to accept a proportion of applicants who were either "inexperienced at working for wages in domestic service" or only "slightly experienced". New South Wales, Queensland and Western Australia were persuaded to take these emigrants. ${ }^{74}$ Although more labour was brought to Australia in this way, the adaptations to policy reinforced the criticism of the inadequate occupational skills of immigrants.

Assessment procedures were not, however, one-sided. Single women also interviewed the selecting officials and assessed the emigration publicity and information given to them. There is ample evidence that single women gave considerable thought to emigration and compared migration schemes and the wages and conditions prevailing abroad. ${ }^{75}$ The Society for the Oversea Settlement of British Women, for example, reported that some women came

71. Commonwealth of Australia, Parliamentary Papers (CAPP), 1926-1927-1928, vol. V, Report of the High Commissioner of the Commonwealth in the United Kingdom. Report for the Year 1925, p. 26. Australian Archives (AA), Canberra, CP 21I/2/I, Bundle 97, Monthly Reports, 1927; Society for the Oversea Settlement of British Women (SOSBW), Council Report, II January I928; SR GRG7/23/1913/135, 8 September 1913, Appendix A.

72. Ministry of Labour, Annual Reports, 1922-1930. Statistics were published from August 1922, but none were included for 1926. Assistance was given to 1,304 out of 3,608 applicants. The Ministry of Labour supplied a minority of the total number of applicants.

73. SR GRG 7/54, I December I9II; SR GRG 7/23/1913/135, 7 January 19I4. "Home girls" were those who had been occupied in domestic work in their own or relatives' homes, but had not worked for wages in the occupation.

74. SR GRG 7/23/192I/32I; GRG 7/24/1925/43.

75. SR GRG 7/53, 2I September 19II, Ellen Joyce to Agent-General for South Australia, undated letter with correspondence; SR GRG 7/23/1913/135, October 1913. For a discussion concerning the independence and enterprising behaviour of assisted single women emigrants, see Margrette Kleinig, "Independent Women - South Australia's Assisted Immigrants 1872-1939", in Eric Richards (ed.), Visible Women: Female Immigrants in Colonial Australia: Visible Immigrants Four (Canberra, 1995). 
into their London office three or four times to discuss the implications of emigration before making up their mind to proceed with their application. ${ }^{76}$ Women also withdrew after selection. The transition for domestic servants from rural to urban environments in the United Kingdom could be traumatic. ${ }^{77}$ The impact of an even more momentous departure from "home", changes in climate and the novelty, excitement and at times the stress of the voyage, seem to have been the cause of many publicized complaints about the behaviour and employment difficulties of immigrant single women on disembarkation. Certainly, those involved in managing the migration schemes explicitly recognized ways in which the transition affected women. ${ }^{78}$ The assessment and selection procedures in regard to both personal and occupational criteria were therefore rigorous and single women jumped high hurdles for their passage tickets. However, the contemporary criticisms concerning, for example, "townie typists" remained. Can the occupational criteria be further examined?

The difficulties involved in quantifying and intepreting women's working lives in the United Kingdom have been discussed by historians of women's work who point out that the nineteenth-century British census did not always enumerate the details of women's working lives. ${ }^{79}$ It did not capture the temporary or seasonal nature of some work, or the obligations of extended family commitments. Women moved in and out of the paid workforce in response to these factors and to their own preferences and choices. These complexities are evident in the work histories of the emigrant women who came to South Australia between the wars. For example, one young woman who lived in Ayr, Scotland, described her occupation as "farm servant" to emigration officials in March 1925. She had worked for eighteen months across the Firth of Clyde, on Arran, but had not re-engaged at the end of the previous summer season. ${ }^{80}$ Another woman, who was thirty years of age, stated that she had "no present occupation". She had, however, for the previous two years, "taken over the entire responsibility of my sister's housework" ${ }^{81}$ Her former waged employment had been as a clerk. A third woman was currently working as a weaver but was also engaged in unpaid

76. SOSBW, Seventh Annual Report, I January to 3I December 1926.

77. Theresa M. McBride, The Domestic Revolution: The Modernisation of Household Service in England and France I820-1920 (London, 1976), p. 70.

78. AA, AI, 32/7627, Extract from Summary Report No. I5, Miss Jacobs, 30 June 1929; SR GRG 7/23/1912/50.

79. See, for example, Edward Higgs, "Women, Occupations and Work in the Nineteenth Century Censuses", History Workshop Journal, 23 (Spring 1987), pp. 59-80; idem, "Domestic Service and Household Production”, in Angela V. John (ed.), Unequal Opportunities: Women's Employment in England I800-19I8 (Oxford, I986); Bridget Hill, "Women, Work and the Census: A Problem for Historians of Women”, History Workshop Journal, 35 (Spring 1993), pp. 78-94; Elizabeth Roberts, Women's Work 1840-1940 (Basingstoke, I988).

8o. SR GRG $7 / 8 / 584$.

8I. SR GRG $7 / 8 / 430$. 
domestic work for her married brother, "as the weaving is slack and does not fill [my] time". ${ }^{82}$

How typical were these three women of those who came to South Australia between the wars? Although we know that there were expanding occupational opportunities for women in England from the late nineteenth century, we are reminded that from the middle of the nineteenth century until the Second World War, "the typical working-class female job [...] was domestic service". ${ }^{83}$ What was the actual situation with South Australia's immigrant women?

Between 1921 and 1939, 877 selected domestic helpers disembarked in South Australia. ${ }^{84}$ We have occupational data for 707 of them. ${ }^{85}$ As with all occupational categories, there are definitional problems with domestic service. There is a great difference in status, skill and wages remuneration between, for example, a cook in a large household of servants and an indoor farm servant. There could also be differences within categories, based on training, skill and experience. While the category of servant most in demand and the one judged to be the ideal worker for Australian conditions was the "general", who could cook, wash and clean, the women requisitioned by the governments of South Australia between the wars were expected to be "experienced" in the broad classification of "domestic servant" and 89 per cent of the 707 women who received assisted passages as selected domestic helpers were experienced in at least one form of domestic service. A number stated that they had worked in two or more categories of service, for example, as a housemaid, general servant and cook. ${ }^{86}$

The responses of these women to the question about their length of service as domestic workers are compiled and presented in Figure 5. Not only was an overwhelming majority of selected domestic helpers experienced in domestic service, but over 70 per cent are recorded as having worked in the occupation for more than three years. ${ }^{87}$

82. SR GRG $7 / 8 / 46$.

83. Roberts, Women's Work, p. 17. See also Jane Lewis, Women in England I870-1950: Sexual Divisions and Social Change (Brighton, 1984), pp. 156-158.

84. SR GRG Series 7/8; 7/9, 7/15. The figure includes ex-servicewomen who accepted "situations" through the Immigration Department and selected Salvation Army and Church Army domestic workers who were granted government-assisted passages. A few Salvation Army women disembarked in Melbourne and travelled on to Adelaide.

85. The figure omits emigrant women who underwent a course in domestic service at the Market Harborough training college in Leicestershire to prepare them for emigration within the domestic helper scheme. Less than fifty in number, they were officially termed "trainees" and comprised a different category in recruitment.

86. The few women who had undertaken domestic science or cooking courses which qualified applicants for a selected passage are classed as experienced domestic servants.

87. The women who had undertaken domestic science courses are tabulated as working in the occupation for less than six months. "Length of service" is not recorded for a number of women and is entered as "unspecified". For a few women information is available from other sources, a referee or ship's matron for example. This alternative source is used in Figure 5. A number of the 


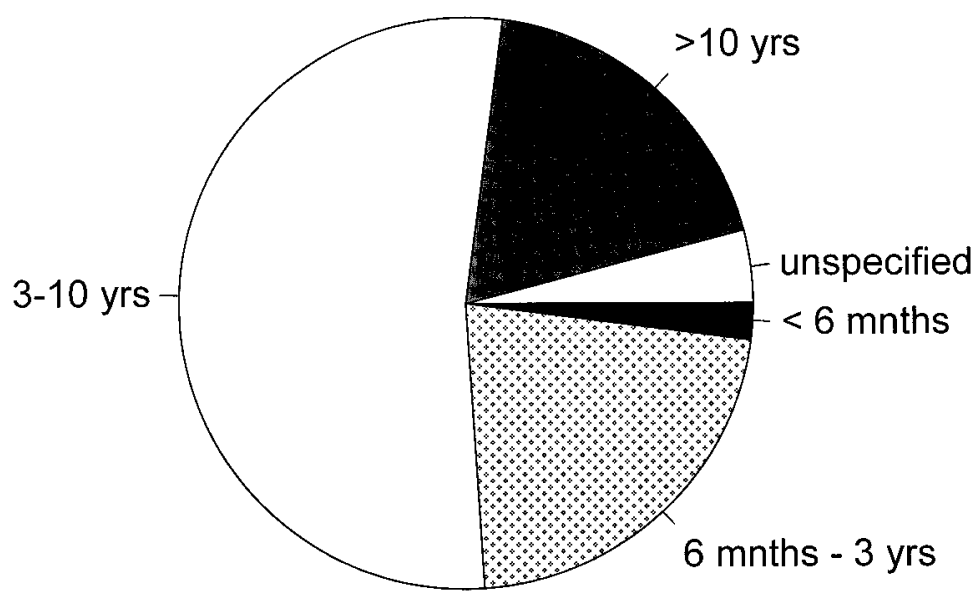

Figure 5. Length of service within the general classification of domestic service, I92I-1939 Source: Statistical Register of South Australia 7/8, 7/15.

A third of the women who had been employed as domestic servants could be broadly termed multi-skilled. That is, they had worked in another occupation. ${ }^{88}$ The newer occupations for women, in manufacturing and light engineering, retailing, confectionary manufacture and office work were well represented, as well as the more traditional work - as weavers, dressmakers and milliners. A large proportion of the newer occupations can be technically designated semi-skilled, for instance, packers, telephonists, mail sorters, production assemblers or munition workers. These experiences demonstrate the variety of work undertaken by women in an expanding market. One twenty-one-year-old woman was perhaps the archetypal "modern woman" in occupational terms. She gave her occupation as "washing and cutting films" and her employer was Kodak Limited. She had also worked in two other occupations - in chocolate making and as a domestic servant. ${ }^{89}$ A number of single women across all occupations seem to have combined familial obligations with paid work. They often lived and worked in their own or a relative's home for a time and moved in and out of waged employment.

The II per cent who stated that they had never worked for wages in domestic service, or had worked only in their own or relatives' homes,

women who had worked as domestic servants for more than ten years often answered "all my life" or "since leaving school" to this question.

88. Information within this category is not available for all 707 women. The proportion excludes women who recorded that their only alternative occupation was waitressing, but includes women who had been involved in any form of "war work" (munitions, canteens, etc.) and outdoor work, such as gardening and dairy-work.

89. SR GRG 7/8/83I. 
indicated this fact clearly to recruiters. Almost three-quarters of these women deliberately sought a passage to South Australia. They were part of chain migration and had friends or relations in the state, or had been engaged by South Australian employers, or simply stated a preference for the state. Migration officials were therefore responding to the request of an emigrant in sending her to South Australia. An additional 8 per cent of this small group arrived in South Australia as part of an emigrant party organized by either the Church Army or Salvation Army emigration societies in England. These organizations were part of the recruiting system and usually supported their emigrants on arrival. Most of the women who indicated that they had no previous experience in domestic service were therefore emigrating under what were considered to be optimum personal conditions: to a preferred destination or one which offered the support of family, friends, or an emigration society.

Thus an analysis of the Immigration Department selection procedures and the occupational histories of single women demonstrates that, between the wars, South Australia's immigrant domestic helpers were experienced servants. Indeed the majority indicated that they had worked in no other occupation. South Australia's demands concerning the occupational qualities of these labour immigrants were fulfilled and the women met the requirements of the labour market for which they were recruited.

\section{PERSPECTIVES}

These stories of Irish, assisted and domestic servants' migrations chime together in an increasingly symphonic rehabilitation and celebration of the colonial Australian proletariat. The new Australian research is, of course, contributing to the broader historical task of doing justice to labouring people in the past, en masse. This is the problem of devising a realistic way of describing (in this case) the I.6 million people who entered Australia, and relating them to the great structural changes then proceeding in the British Isles. The quantitative approach renders them in digitalized form, rather skeletal at the best of times. The cameo method offers vivid evocations of individual immigrants, with ample flesh and blood, though they may be historical aberrations in terms of representing the mass. Evidently the methodological trick is to marry the two approaches, to double their value.

The stark discontinuities in Australian immigration - for instance, between convict and assisted migrant flows - is evidently diminished by this recent research. The redefinition of the incoming colonial population, inevitably, presents several residual problems. One is the growing tension between the positive characterizations of the immigrants as human capital offered by the new school of historians, as against the loudly negative perceptions of immigrants uttered by so many colonial employers and contem- 
poraries throughout the nineteenth century. It will always be necessary to allow for profoundly prejudicial preconceptions by employers who were constantly looking for the cheapest and best labour. In addition, however, we should incorporate in our explanations the individual and collective psychologies of colonial employers and the relationships between the two parts of Australia's bifurcated immigration systems, the assisted and the unassisted. Ultimately, the best test of the qualities of the incoming migrants was the manner in which they were taken into the labour force, and their actual utility, after arrival, as colonial workers and citizens. This, rather than initial employers' reaction, was the acid test of immigrant labour.

Any account of the incoming workers of the nineteenth century has to cope with the sheer heterogeneity and diversity of these people, however much we may stretch and strain after organizing patterns. In the Australian case, it is certainly difficult to conjure up, from literature or art, the image of the emaciated and ragged immigrant so prevalent in American immigrant iconography. Among the British and Irish immigrants to Australia were peasants and proletarians, rich and poor, refugees and escapees, the rural and the urban, skilled and unskilled, sick and healthy, Londoners, Shetlanders, Channel Islanders; there were the good and even the bad. Over historical time the mixes changed and the proportions shifted: the patterns overlapped and often they defy description. The Australian historiography is in a state of redefinition, and the kaleidoscope has some new and interesting shapes. 